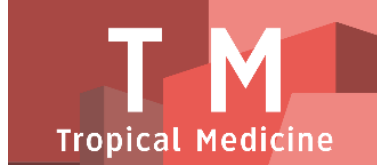

PAPER - OPEN ACCESS

Pengaruh Teknik dan Pelarut Ekstraksi Terhadap Aktivitas Antioksidan dari Empat Jenis Ekstrak Daun Rosella (Hibiscus sabdariffa L.)
Author
: Ari Sri Windyaswari
DOI
: 10.32734/tm.v1i3.254
Electronic ISSN
: 2623-0542
Print ISSN
: 2623-0550

Volume 1 Issue 3-2018 TALENTA Conference Series: Tropical Medicine (TM)

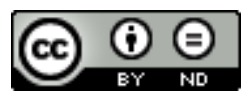

This work is licensed under a Creative Commons Attribution-NoDerivatives 4.0 International License.

Published under licence by TALENTA Publisher, Universitas Sumatera Utara
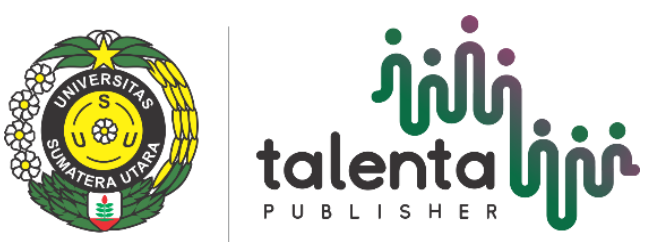


\title{
Pengaruh Teknik dan Pelarut Ekstraksi Terhadap Aktivitas Antioksidan dari Empat Jenis Ekstrak Daun Rosella (Hibiscus sabdariffa L.)
}

\author{
Ari Sri Windyaswari ${ }^{a^{*}}, Y$ Yenni Karlina ${ }^{\mathrm{b}}$, Amalia Junita ${ }^{\mathrm{c}}$ \\ ${ }^{a b c}$ Kelompok Keahlian Biologi Farmasi, Fakultas Farmasi, Universitas Jenderal Achmad Yani, Bandung
}

ari.sri.w@unjani.lecture.ac.id

\begin{abstract}
Abstrak
Tanaman rosella merupakan tanaman asli dari benua Asia (India hingga Malaysia) dan benua Afrika. Kultivasi bagian bunga, daun, dan biji dari tanaman rosella (Hibiscus sabdariffa L.) telah lama digunakan oleh masyarakat sebagai bahan makanan dan pengobatan empiris. Hasil penelitian sebelumnya menunjukkan tanaman rosella memiliki aktivitas farmakologi sebagai antikanker, antibakteri dan antioksidan. Telah dilaporkan bahwa bagian daun dan akar rosella dilaporkan mengandung senyawa fenolik terbanyak dibandingkan dengan bagian lainnya. Penelitian ini bertujuan untuk mengetahui pengaruh teknik dan pelarut ekstraksi terhadap aktivitas antioksidan dari empat jenis ekstrak daun rosella (Hibiscus sabdariffa L.). Teknik ekstraksi yang dilakukan adalah maserasi, infus dan refluk menggunakan pelarut air dan pelarut etanol. Aktivitas peredaman radikal bebas DPPH teridentifikasi pada pola kromatogram lapis tipis dengan penampak bercak DPPH 0,2\% dari seluruh ekstrak daun rosella. Pengujian aktivitas antioksidan menggunakan metode peredaman radikal bebas DPPH dilakukan terhadap seluruh ekstrak daun rosella, yaitu ekstrak air teknik maserasi (AM), ekstrak air teknik infus (AI), ekstrak etanol teknik maserasi (EM), serta ekstrak etanol teknik refluk (ER). Nilai $I C_{50}$ ekstrak AM, AI, EM dan ER berturut-turut adalah: 0,00056 ppm (sangat kuat); 0,00057 (sangat kuat); 0,00044 ppm (sangat kuat); 0,00092 ppm (sangat kuat). Metode penyarian metabolit sekunder optimal untuk aktivitas antioksidan pada daun rosella adalah teknik ekstraksi maserasi dengan pelarut etanol (ER).
\end{abstract}

Kata kunci : Rosella (Hibiscus sabdariffa L.), daun, anti oksidan, DPPH

\begin{abstract}
One of natural antioxidant source, the rosella plant (Hibiscus sabdariffa L.) is original plant from Asia and Africa. The cultivation of rosella plant in beverages and herbal remedies are very popular. On the previous research, each part of the plant (flowers, calyces, stems, roots, seeds and leaves) has anti oxidant capability nor the leaves and roots has higher phenolic contents. The objective of this research is to optimize extraction techniques and solvents in antioxidant properties from four Rosella leaf extracts. The differences among the extracts are in the technique of extraction (maceration, infusion, reflux) and solvents use (water, ethanol). The extracts using maceration and infusion techniques with water solvent are AM, AI. The extracts using maceration and reflux techniques with ethanol solvent are EM, ER. Determination of antioxidant property from four different extracts of Rosella leaf is performing by DPPH (1,1-diphenyl-2-picrylhidrazil) method. By means, the chromatogram pattern in all various extracts using DPPH $0.2 \%$ as spray detection for the antioxidant activities are identified. The $I C_{50}$ value from AM, AI, EM and ER extracts are $0,00056 \mathrm{ppm}$ (very strong), 0,00057 (very strong), 0,00044 ppm (very strong); 0,00092 ppm (very strong), respectively. The result indicates that ethanol extract with maceration technique (ER) possesses more antioxidant activities compare to the others.
\end{abstract}

Keywords: Rosella (Hibiscus sabdariffa L.), leaf, antioxidant, DPPH 


\section{Pendahuluan}

Tanaman rosella termasuk ke dalam keluarga Malvaceae, merupakan tanaman asli dari benua Asia dan benua Afrika. [1]. Herba Rosella mengandung flavonoid hibisitrin, hibisetin. Bagian daun dan batang mengandung senyawa asam dan fenolik. Kelopak bunga kaya akan senyawa asam sitrat dan pektin. Bagian bunga mengandung pigmen mayor teridentifikasi daphniphylline. Kelopak kuncup bunga mengandung flavonoid gosipetin, dan sabdaretin, alkaloid, $\beta$ sitosterol, antosianin, asam sitrat, sianidin-3-glukosa, delfinidin, galaktosa, pectin, asam protokatekuat, kuarsetin, asam stearat, dan lilin [2]

Biji mengandung protein, lemak dan serat, serta mineral-mineral. Minyak biji mengandung $70 \%$ asam lemak tak jenuh, dengan salah satu komponen besar adalah asam linoleat (44\%), steroid dan tokoferol [3]. Buah mengandung pektin, anisaldehid, asam sitrat, asam asetat, asam format, asam felagonat dan mineral-mineral. Akar mengandung asam tartrat dan saponin Hasil penelitian dilaporkan bahwa tanaman rosella memiliki aktivitas anti hipertensi, hepatoprotektor, anti hiperlipidemia, anti kanker, antibakteri dan anti oksidan. Bagian daun dilaporkan memiliki aktivitas antiseptik, antihipertensi, dan sedatif. [4]. Aktivitas antioksidan dari kelopak bunga kering Rosella pada ekstrak metanol yang difraksinasi, menunjukkan aktivitas peredaman radikal bebas sangat tinggi (70-80\%) pada fraksi kloroform dan fraksi etil asetat. [1]

Pada penelitian ini akan dilakukan optimasi teknik ekstraksi dan pelarut terhadap aktivitas antioksidan empat jenis ekstrak etanol daun rosella yang diharapkan dapat bermanfaat untuk penelitian selanjutnya ke arah uji aktifitas farmakologi atau pengembangan sediaan bahan alam.

\section{Bahan dan Metode}

\subsection{Bahan}

Daun rosella hasil budidaya dikumpulkan dari daerah Parongpong, Lembang, dengan metode pemetikan acak kemudian dilakukan determinasi di Herbarium Bandungense, Sekolah Tinggi Ilmu Hayati ITB untuk memastikan kebenaran identitas. Daun segar yang diperoleh, disortasi basah, dikeringkan, sortasi kering, kemudian dihaluskan menjadi serbuk simplisia kasar. dikeringkan pada suhu $40^{\circ} \mathrm{C}$, kemudian dilakukan pengecilan ukuran partikel hingga menjadi serbuk simplisia kasar.

Pemeriksaan karakteristik simplisia meliputi pemeriksaan makroskopik dan mikroskopik, penetapan kadar air, penetapan kadar abu total, penetapan kadar abu larut air, penetapan kadar abu tidak larut asam, penetapan kadar sari larut air, dan penetapan kadar sari larut etanol.

\subsection{Metode}

\subsubsection{Pembuatan ekstrak AM, AI}

Sebanyak 500 gram serbuk simplisia daun rosella ditambahkan pelarut air suling (1:7) kemudian diekstraksi menggunakan dengan teknik maserasi (AM) dan infus (AI). Proses maserasi berlangsung selama 24 jam dengan intensitas pengadukan setiap 6 jam. Pengulangan dilakukan sebanyak tiga kali hingga didapat filtrat tembus cahaya (bening). Hasil rendemen ekstrak yang diperoleh kemudian dipekatkan dengan cara diuapkan pelarutnya dengan rotary evaporator hingga diperoleh ekstrak kental. Penetapan bobot jenis ekstrak dilakukan dengan membuat konsentrasi $1 \%$ dari ekstrak kental.

\subsubsection{Pembuatan ekstrak EM, ER}

Sebanyak 500 gram serbuk simplisia daun rosella ditambahkan pelarut etanol 96\% (1:7) kemudian diekstraksi menggunakan dengan teknik maserasi (EM), (ER). Proses maserasi berlangsung selama 24 jam dengan intensitas pengadukan setiap 6 jam. Pengulangan dilakukan sebanyak tiga kali hingga didapat filtrat tembus cahaya (bening). Hasil rendemen ekstrak yang diperoleh kemudian dipekatkan dengan cara diuapkan pelarutnya dengan rotary evaporator hingga diperoleh ekstrak kental. Penetapan bobot jenis ekstrak dilakukan dengan membuat konsentrasi $1 \%$ dari ekstrak kental. 


\subsubsection{Penapisan Fitokimia Simplisia dan Ekstrak}

Penapisan fitokimia yang dilakukan pada simplisia dan ekstrak etanol $96 \%$ daun rosella meliputi pemeriksaan golongan metabolit sekunder alkaloid, polifenol, tanin, flavonoid, kuinon, saponin, terpenoid, dan steroid/triterpenoid.

\subsubsection{Uji Kualitatif Aktivitas Antioksidan}

Uji kualitatif aktivitas antioksidan dilakukan secara KLT dengan fase gerak yang sesuai untuk setiap ekstrak dan penampak bercak DPPH 0,2\% dalam metanol. Hal ini bertujuan untuk mendeteksi adanya komponen antioksidan yang bereaksi positif terhadap penampak bercak DPPH pada masing-masing ekstrak. Sebanyak $10 \mu \mathrm{L}$ ekstrak dengan konsentrasi 1\% ditotolkan pada pelat KLT silika gel GF254 kemudian dikembangkan dengan fase gerak yang sesuai. Selanjutnya, pelat KLT disemprot dengan penampak bercak DPPH 0,2\% dalam metanol. Komponen ekstrak yang memiliki aktivitas antioksidan akan berwarna kuning dengan latar belakang ungu.

\subsubsection{Uji Kuantitatif Aktivitas Antioksidan Metode DPPH}

Sampel dilarutkan dalam metanol dengan konsentrasi 50 ppm kemudian ditambah dengan larutan DPPH dengan konsentrasi $50 \mathrm{ppm}$ (perbandingan volume 1:1). Campuran tersebut diinkubasi selama 30 menit dan absorbansi diukur pada panjang gelombang $516 \mathrm{~nm}$. Aktivitas antioksidan diukur sebagai persen penurunan absorbansi DPPH pada sampel uji. [5]

Dibuat 6 variasi konsentrasi sampel uji/pembanding kuersetin, kemudian diambil $2 \mathrm{~mL}$ sampel uji/pembanding dicampurkan dengan $2 \mathrm{~mL}$ larutan DPPH (1:1), diinkubasi selama 30 menit, lalu absorbansi diukur pada $\lambda 516 \mathrm{~nm}$. Untuk menentukan IC50 diperlukan persamaan regresi linier dari kurva kalibrasi, dengan persentase peredaman sebagai sumbu y dan konsentrasi antioksidan sebagai sumbu $\mathrm{x}$.

\section{Hasil Dan Pembahasan}

Simplisia daun rosella memiliki warna kehijauan, dan berbau khas. Karakteristik simplisia daun rosella disajikan pada Tabel 1 berikut :

Tabel 1. Karakteristik Simplisia Daun Rosella

\begin{tabular}{clc}
\hline No. & \multicolumn{1}{c}{ Parameter } & Hasil $(\%)$ \\
\hline 1. & Kadar air & $3,60^{*}$ \\
2. & Kadar abu total & $6,59^{* *}$ \\
3. & Kadar abu larut air & $1,61^{* *}$ \\
4. & Kadar abu tidak larut asam & $0,76^{* *}$ \\
5. & Kadar sari larut air & $24,80^{* *}$ \\
6. & Kadar sari larut etanol & $17,77^{* *}$ \\
\hline
\end{tabular}

Keterangan:
$(*): \% \mathrm{v} / \mathrm{b}$
$(* *): \% \mathrm{~b} / \mathrm{b}$

Penapisan fitokimia ini dilakukan terhadap simplisia dan ekstrak AM, AI, EM dan ER daun rosella. Simplisia dan ekstrak AM, AI, EM dan ER mengandung golongan flavonoid, polifenol, tanin, kuinon, monoterpenoid seskuiterpenoid dan saponin. Golongan steroid dan triterpenoid terindentifikasi pada ekstrak etanol 96\% EM dan ER. Sementara itu, golongan saponin teridentifikasi pada ekstrak air AM dan AI. Hasil penapisan fitokimia disajikan pada Tabel 2 berikut : 
Tabel 2 Hasil Penapisan Fitokimia Simplisia dan Ekstrak Daun Rosella

\begin{tabular}{|c|c|c|c|c|c|c|}
\hline No. & Golongan senyawa & $\mathrm{S}$ & $\mathrm{AM}$ & $\mathrm{AI}$ & EM & ER \\
\hline 1. & Alkaloid & - & - & - & - & - \\
\hline 2. & Flavonoid & + & + & + & + & + \\
\hline 3. & Polifenol & + & + & + & + & + \\
\hline 4. & Tanin & + & + & + & + & + \\
\hline 5. & Kuinon & + & + & + & + & + \\
\hline 6. & Monoterpenoid-seskuiterpenoid & + & + & + & + & + \\
\hline 7. & Steroid/triterpenoid & - & - & - & + & + \\
\hline 8. & Saponin & + & + & - & - & - \\
\hline
\end{tabular}

Keterangan :

(+) : Mengandung metabolit sekunder

(-) : Tidak mengandung metabolit sekunder

$\mathrm{S}$ : Simplisia

Pada penapisan golongan flavonoid, reaksi dinyatakan positif dengan terbentuknya warna kuning-merah pada lapisan amil alkohol. Warna merah ini terbentuk akibat adanya reaksi reduksi pada gugus karbonil menjadi gugus alkohol membentuk senyawa hidroksi yang berwarna dan warna tersebut kemudian ditarik oleh amil

alkohol. Golongan polifenol dinyatakan positif dengan terbentuknya warna biru kehitaman setelah penambahan besi (III) klorida. [4] Senyawa tanin dinyatakan positif dengan menambahkan pereaksi gelatin dan terbentuk endapan putih keabuan. Keberadaan senyawa kuinon ditunjukkan dengan kemampuannya membentuk garam berwarna kuning sampai merah saat direaksikan dengan larutan alkali kuat $(\mathrm{NaOH}$ atau $\mathrm{KOH})$. Senyawa saponin dinyatakan positif ditandai dengan terbentuknya busa setinggi $1 \mathrm{~cm}$ pada pengocokan dan stabil setelah penambahan asam klorida $0,1 \mathrm{~N}$. Busa yang terbentuk menunjukkan adanya saponin karena saponin merupakan senyawa yang memiliki sifat seperti sabun yaitu berdasarkan kemampuan membentuk busa. [6]

Golongan monoterpen/seskuiterpen akan menbentuk reaksi warna apabila direaksikan dengan reagen vanillin sulfat. Golongan steroid dan triterpenoid akan membentuk warna apabila direaksikan dengan pereaksi Liebermann-Burchard karena gugus $\mathrm{OH}$ pada kerangka steroid dan triterpenoid jika direaksikan dengan asam sulfat pekat, maka asam sulfat pekat dapat menarik air dari senyawa tersebut, sehingga dengan hilangnya atom hidrogen dan oksigen dalam bentuk air, maka biasanya terbentuk ikatan rangkap terkonjugasi, atau membentuk senyawa baru yang menghasilkan warna. [6] Penetapan bobot jenis ekstrak bertujuan untuk memberi batas besar massa per satuan volume yang merupakan parameter khusus ekstrak cair yang dapat dituang. Hasil penetapan bobot jenis ekstrak daun rosella disajikan dalam Tabel 3 berikut :

Tabel 3. Hasil Penetapan Bobot Jenis Ekstrak Daun Rosella

\begin{tabular}{lll}
\hline No. & Bobot Jenis & Hasil $(\mathrm{g} / \mathrm{ml})$ \\
\hline 1 & AM & 1,0056 \\
2 & AI & 1,0079 \\
3 & EM & 0,8181 \\
4 & ER & 0,8135 \\
\hline
\end{tabular}

Berdasarkan hasil pemantauan pola kromatogram KLT, diketahui bahwa golongan flavonoid dan fenolik yang berfluoresensi terang dibawah sinar $\mathrm{UV}_{356 \mathrm{~nm}}$ diduga bertanggungjawab terhadap aktivitas antioksidan. 


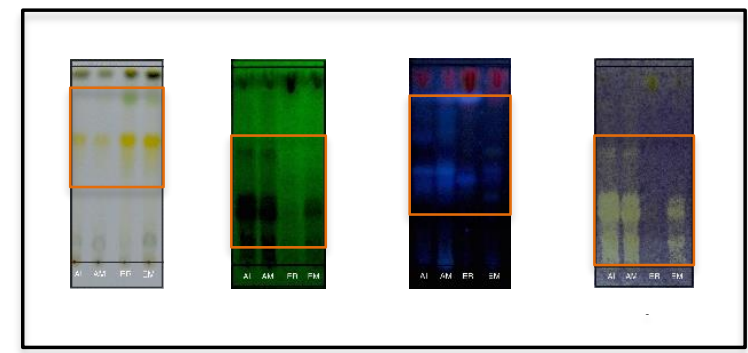

Gambar 2.Pola Kromatogram Lapis Tipis Ekstrak Daun Rosella AI, AM, EM, ER

Keterangan :

Pola Kromatogram Lapis Tipis (a): visual, (2): Sinar $\mathrm{UV}_{254 \mathrm{~nm}}$, (3): Sinar $\mathrm{UV}_{356 \mathrm{~nm}}$, (4) Penampak Bercak DPPH 0,2\%, fase gerak EtOH:EtOAc:H $\mathrm{H}_{2} \mathrm{O}$ (7,7: 1,3: 1), fasa diam pelat silika $\mathrm{GF}_{254}$

Parameter yang digunakan untuk pengukuran aktivitas antioksidan sampel uji menggunakan IC50 yaitu bilangan yang menunjukkan konsentrasi ekstrak yang mampu menghambat aktivitas suatu radikal sebesar 50\%. Semakin kecil nilai IC50 menunjukkan semakin tinggi aktivitas antioksidan. Suatu ekstrak dinyatakan memiliki aktivitas antioksidan yang sangat kuat apabila memiliki nilai IC50 kurang dari 50 ppm, dinyatakan kuat apabila memiliki nilai IC50 50100 ppm, dinyatakan sedang apabila memiliki nilai IC50 $101-150 \mathrm{ppm}$, dan dinyatakan lemah apabila memiliki nilai IC50 > 150 ppm. [5]

Nilai konsentrasi ekstrak yang mampu meredam 50\% radikal bebas (IC50) digunakan untuk penentuan kekuatan aktivitas antioksidan dari sampel uji terhadap pembanding. Kekuatan aktivitas antioksidan sampel uji dihitung menggunakan persamaan regresi linier dari kurva kalibrasi pembanding yang telah diukur sebelumnya. Uji aktivitas antioksidan ekstrak AM, AI, EM, ER daun rosella dengan Metode DPPH disajikan pada Tabel 4 berikut :

Tabel 4 Uji Aktivitas Antioksidan Ekstrak Daun Rosella

\begin{tabular}{ccccc}
\hline Ekstrak & Jenis & $\begin{array}{c}\text { Aktivitas Peredaman } \\
\text { DPPH }(\%)\end{array}$ & $\begin{array}{c}\text { Nilai } I C_{50} \\
(\mathrm{ppm})\end{array}$ & Intensitas \\
\hline \multirow{2}{*}{ Air } & AM & 50,71 & 0,00056 & Sangat kuat \\
& AI & 50,69 & 0,00057 & Sangat kuat \\
Etanol 96\% & EM & 51,62 & 0,00044 & Sangat kuat \\
& ER & 49,48 & 0,00092 & Sangat kuat \\
\hline
\end{tabular}

Dari hasil uji aktivitas antioksidan dapat dilihat bahwa peredaman radikal bebas DPPH tertinggi adalah ekstrak etanol sampel EM $\left(51,62 \%, I C_{50}=0,00044 \mathrm{ppm}\right)$, diikuti dengan ekstrak air sampel AM $\left(50,71 \%, I C_{50}=0,00056\right.$ ppm), ekstrak air sampel AI $\left(50,69 \%, I C_{50}=0,00057 \mathrm{ppm}\right)$, dan ekstrak etanol sampel ER $\left(49,48 \%, I C_{50}=0,00092\right.$ ppm). Nilai $I C_{50}$ pada ekstrak air AM dan AI idak memberikan perbedaan signifikan. Nilai $I C_{50}$ pada ekstrak etanol EM memberikan intensitas terkuat diantara semua ekstrak, sementara itu nilai $I C_{50}$ ER memberikan aktivitas antioksidan terlemah diantara semua ekstrak.

\section{Kesimpulan}

Berdasarkan hasil diatas, dapat disimpulkan bahwa perbedaan teknik ekstraksi dan pemilihan jenis pelarut akan memberikan aktivitas antioksidan yang berbeda pada daun rosella. Teknik ekstraksi cara panas dan dingin menggunakan pelarut air, tidak memberikan pengaruh signifikan terhadap aktifitas antioksidan daun rosella, namun pada pelarut etanol, pemilihan teknik ekstraksi akan memberikan pengaruh signifikan terhadap aktivitas antioksidan daun rosella. 


\section{Ucapan Terima Kasih}

Penulis mengucapkan terima kasih kepada Lembaga Penelitian dan Pengabdian Masyarakat (LPPM) Universitas Jenderal Achmad Yani (UNJANI) yang telah memberi dukungan finansial terhadap penelitian ini, serta kepada Dekan Fakultas Farmasi UNJANI atas fasilitas yang telah diberikan

\section{Daftar Pustaka}

[1] Abdallah, M.E., 2016. Antibacterial Activity of Sudanese roselle Hibiscus sabdariffa Linn., a famous beverage from Sudanese folk medicine, J Intercult Ethnopharmacol. 2016 Mar-Apr; 5(2): 186-190, Qassim University, Saudi Arabia.

[2] Mahadevan M., Shivali, Kamboj Pi, 2009. Hibiscus sabdariffa Linn : an overview, Natural Product Radiance, Vol 8 (1), $77-83$.

[3] Mungole, A., Chaturvedi, A., 201. Hibiscus sabdariffa Linn A Rich Source of Secondary Metabolites, Vol.6, Issue 1, Article 018.

[4] Quisumbing, E., 1978. Medical Plants of the Phillippines Katha Publishing, Quezon City, Phillippines. Halaman 640- 642

[5] Molyneux, P., 2003. The Use of Stable Free Radical Diphenylpicrylhydrazyl (DPPH) for Estimating Antioxidant Activity, Journal of Science Technology, 26(2), 211-21

[6] Farnsworth, N.R., 1966. Biological and phytochemical screening of plants, J Pharm Sci. 1966 Mar;55(3):225-76.

[7] Anonim, 1995. Farmakope Indonesia Edisi IV, Departemen Kesehatan Republik Indonesia, Direktorat Jenderal Pengawasan Obat dan Makanan RI, Jakarta.

[8] Anonim, 2000. Parameter Standar Umum Ekstrak Tumbuhan Obat, Departemen Kesehatan Republik Indonesia, Direktorat Jenderal Pengawasan Obat dan Makanan, Direktorat Pengawasan Obat Tradisional, Jakarta.

[9] Badan Penelitian dan pengembangan Kesehatan, 1994. Inventaris Tanaman Obat Indonesia Jilid II, Departemen kesehatan RI Halaman 123124

[10] Blois, M.S., 1958. Antioxidant Determination by the use of Stable Free radicals, Nature, 181, 1199-2000

[11] Droge W., 2002. Journal : Free Radicals in the Physiological Control of Cell Function, J Physiological Reviews, (82), 1 , 47-95

[12] Silalahi, J., 2001. Free Radicals and Antioxidant Vitamins in Degenerative Disease. J Indo Med Assoc. II. 1-1

[13] S.B Chandrasekar, M. Bhanumathy, A.T Pawar and T. Somasundaram., 2010. Phytopharmacology, NCBI.

[14] Syed I. R., Neetu M., 2013. Traditional Indian Medicines Used for the Management of Diabetes Mellitus, Hindawi Publishing Corporation, 2

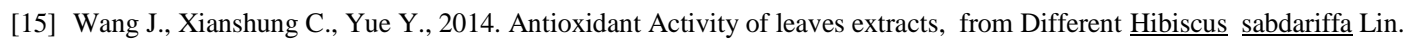

